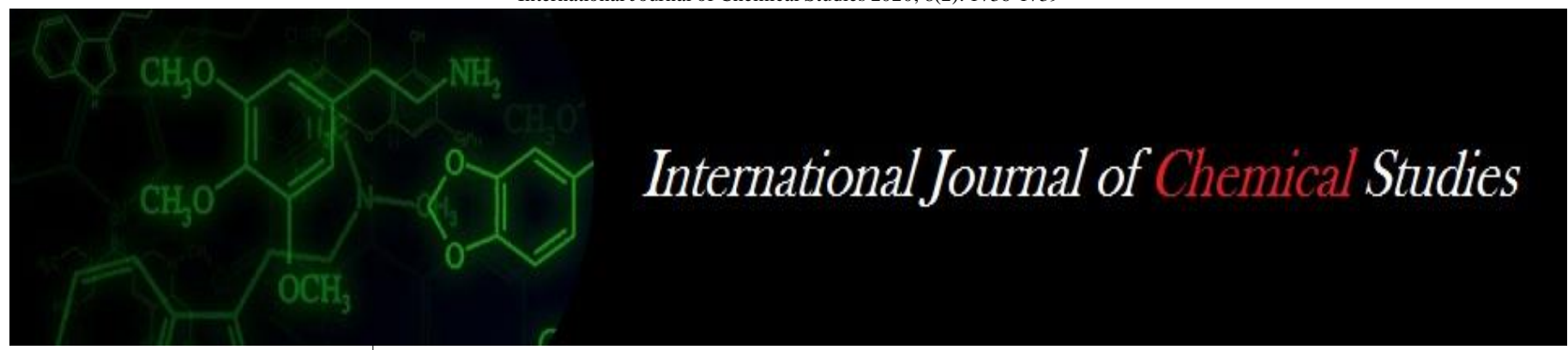

P-ISSN: 2349-8528

E-ISSN: 2321-4902

www.chemijournal.com

IJCS 2020; 8(2): 1736-1739

(C) 2020 IJCS

Received: 12-01-2020

Accepted: 14-02-2020

PA Gaikwad

Department of Plant Pathology, College of Agriculture

Marathwada Krishi Vidyapeeth,

Parbhani, Maharashtra, India

DN Dhutraj

Department of Plant Pathology,

College of Agriculture

Marathwada Krishi Vidyapeeth,

Parbhani, Maharashtra, India

CV Ambadkar

Department of Plant Pathology, College of Agriculture

Marathwada Krishi Vidyapeeth,

Parbhani, Maharashtra, India

Corresponding Author:

PA Gaikwad

Department of Plant Pathology,

College of Agriculture

Marathwada Krishi Vidyapeeth,

Parbhani, Maharashtra, India

\section{Effect of soil moisture regimes and soil types on incidence of Rhizoctonia bataticola causing dry root rot of chickpea}

\author{
PA Gaikwad, DN Dhutraj and CV Ambadkar
}

DOI: https://doi.org/10.22271/chemi.2020.v8.i2aa.9010

\begin{abstract}
Effect of different soil moisture regimes and soil types on incidence of Rhizoctoniabataticola causing dry root of chickpea (Cicerarietinum L.). crop were studied during 2018-19 at VNMKV, Parbhani. In present studiesdry root rot disease incidence was higher (range: 80.00 to 74.45 per cent) at the soil moisture level of 55 to 60 per cent. Whereas it was noticed that sandy soil showed highest dry root rot disease incidence followed by sandy loam soil and than the other soil types.
\end{abstract}

Keywords: R.bataticola, chickpea, soil moisture, soil type

\section{Introduction}

Chickpea is an important Rabi crop sown in September - November and harvested in February. At present, it is grown in over 50 countries of Asia, Africa, America and Oceania in rainfed environments (Sharma et al., 2015) ${ }^{[8]}$. The production of chickpea is largely constrained by Fusarium wilt (Fusariumoxysporumf. sp.ciceris); however, recent reports indicated that dry root rot (DRR) is emerging as a potential threat to chickpea production (Ghosh et al., 2013, Pande et al., 2010 and Sharma et al., 2010) ${ }^{[1,5,10]}$. The dry root rot is caused by Rhizoctoniabataticola (Taub.) Butler. (Synonym: Macrophominaphaseolina (Maubl.) Ashby.) and it is an important component of the disease complex that causes root rots and seedling blight in many grain legumes when they are weakened by other stress factors (Hwang et. al. 2003). It can affect chickpea production, causes considerable yield losses that vary from 5to 50 per cent and may cause 100 per cent losses in susceptible cultivars under favourable condition (Pande et al., 2012) ${ }^{[6]}$ and considerable yield losses which may be as high as 50 to 71 per cent (Veena et.al. 2014a). Considering the economic importantce of disease, present investigation was planned to study the effect of soil moisture regimes and soil types on incidence Rhizoctoniabataticola.

\section{Material and methods}

Effect of soil moisture regimes

Effect of soil moisture levels $(35 \%, 45 \%, 55 \%, 65 \%, 75 \%, 85 \%$ and $100 \%)$ on dry root rot disease incidence was studied in pot / polybag culture experiment, using sick soil ( $R$. bataticola) under screen house conditions. Black coloured nursery polybags (size: 20 x 30 $\mathrm{cm}$.) filled with autoclaved potting mixture of soil : sand (3:1) were inoculated (@50 g / kg mixture) with the test pathogen (Rb-6isolate) mass multiplied (sand: maize medium) culture, watered adequately and incubated for ten days in the screen house to proliferate the pathogen and make the soil / potting mixture sick. Surface sterilized $\left(0.1 \% \mathrm{HgCl}_{2}\right)$ healthy seeds of chickpea JG-62 were sown (10 seed/pot), watered to maintain the soil moisture levels as per treatments. For each treatment, three pots / replication were maintained and all the treatments were replicated thrice. The seedlings were allowed to grow for 10 days under normal conditions. Different levels of per cent soil moisture were maintained 10 days after sowing. The per cent soil moisture was determined using the gravimetric method on an oven dry basis as per the procedure given by Sunkaram (1969) ${ }^{[11]}$. The method includes saturation of soil sample followed by removal of available soil moisture by oven drying $\left(100-110^{\circ} \mathrm{C}\right)$, until the weight remains constant. After removing from oven, samples were cooled slowly to room 
temperature and weighed again. The difference in weight was amount of moisture in the soil. The available per cent soil moisture in the soil was calculated by the following formula.

$$
\begin{aligned}
& \text { Saturated soil weight }- \text { Oven dry soil weight } \\
& \text { Per cent soil moisture }(\%)=0 \text { Oven dry soil weight }
\end{aligned}
$$

The levels of per cent soil moisture was adjusted by maintaining the constant weight by regular weighing and replacing the moisture deficit in each pot by watering.

Observations on per cent disease incidence were recorded at 15, 30 and 45 days after sowing. For scoring the disease incidence, diseased and total plants were counted from each replication and percentage of plants infected in each treatment was calculated by following formula.

$$
\text { Per cent Disease Incidence }=\text { - }-\frac{\text { Number of plants infected }}{\text { Total number of plants examined }}
$$

\section{Effect of soil types}

Effect of five soil types i.e. Black soil, Red soil, Clay soil, Sandy soil and Sandy loam soil was studied on the development of dry root rot incidence under controlled environment. The experiment was conducted on susceptible cultivar JG-62 for dry root rot. Each treatment was replicate three times and each replication consists of two pots (5seeds/pot). Each sterilized soils were infested with $R$. bataticola (Rb-6) (at $50 \mathrm{~g} / \mathrm{kg}$ soil) multiplied on sand-maize medium. The pathogen-infested soil was filled in the 6-inch pots $(2.0 \mathrm{~kg} / \mathrm{pot})$. Sowing in the pots were done four days after pathogen infestation. Ten surface sterilized seeds (soaked in $0.1 \% \mathrm{HgCl}_{2}$ for 1 minute followed by 2 - 3 times washing with sterilized water) of the chickpea dry root rot susceptible cultivar JG-62 were planted in each sick pot.
Observations on per cent disease incidence were recorded at 15, 30 and 45 days after sowing. For scoring the disease incidence, diseased and total plants were counted from each replication and percentage of plants infected in each treatment was calculated by following formula.

$$
\begin{aligned}
& \text { Number of plants infected } \\
& \text { Per cent Disease Incidence = } \\
& \text { Total number of plants examined }
\end{aligned}
$$

\section{Results and discussion}

Effect of soil moisture regimes on the incidence of Rhizoctonia bataticola.

Effect of various soil moisture levels on dry root rot incidencewastested by applying sick soil technique and sowing the seeds of susceptible chickpea cv.JG-62, in pot culture under screen house conditions. The results obtained on the per cent disease incidence at 15, 30 and 45 days after sowing (DAS) are presented in the Table 1 and depicted in PLATE 1 and Fig.1.

\section{Effect on dry root rot incidence}

The results (Table1, PLATE I and Fig.1) obtained at various intervals on the effect of soil moisture regimes on the incidence of dry root rot disease (R.bataticola) in chickpea seed cv.JG-62, revealed that the disease incidence was found to be influenced by the soil moisture regimes.

At 15 DAS, the dry root rot disease incidence was ranged from 6.67 to 100.00 per cent, as against none of the incidence at 100 per cent soil moisture. However, the disease incidence at 35 and 40 per cent soil moisture was significantly highest (each $100.00 \%$ ), which may be due to water stress coupled with R.bataticola M.phaseolinainfection. These were followed by the soil moistures viz., 55 per cent $(43.33 \%)$. At soil moisture above 60 per cent, the disease incidence was found to be decreased drastically in the range of 36.67 to 6.67 per cent.

Table 1: Effect of soil moisture regimes on dry root rot disease incidence in chickpea cv. JG-62 (pot culture)

\begin{tabular}{|c|c|c|c|c|c|}
\hline \multirow{2}{*}{ Tr. No. } & \multirow{2}{*}{ Treatments } & \multicolumn{3}{|c|}{ Disease incidence (\%)* } & \multirow{2}{*}{ Av. Disease incidence (\%)* } \\
\cline { 3 - 5 } & & 15 DAS & 30DAS & 45DAS & $100(90)$ \\
\hline $\mathrm{T}_{1}$ & $35 \%$ & $100(90)$ & $100(90)$ & $100(90)$ & $100(90)$ \\
\hline $\mathrm{T}_{2}$ & $40 \%$ & $100(90)$ & $100(90)$ & $100(90)$ & $80.00(63.43)$ \\
\hline $\mathrm{T}_{3}$ & $55 \%$ & $43.33(41.07)$ & $96.67(83.85)$ & $100(90)$ & $74.45(59.64)$ \\
\hline $\mathrm{T}_{4}$ & $60 \%$ & $36.67(37.14)$ & $86.67(68.85)$ & $100(90)$ & $16.67(23.80)$ \\
\hline $\mathrm{T}_{5}$ & $75 \%$ & $10(18.43)$ & $16.67(23.85)$ & $23.33(28.78)$ & $13.33(20.98)$ \\
\hline $\mathrm{T}_{6}$ & $80 \%$ & $6.67(12.28)$ & $13.33(21.14)$ & $20(26.07)$ & $5.55(10.23)$ \\
\hline $\mathrm{T}_{7}$ & $100 \%$ & $0(0)$ & $6.67(12.28)$ & $10(18.43)$ & 7.32 \\
\hline & S.E. \pm & 12.68 & 8.19 & 10.35 & \\
\cline { 2 - 5 } & C.D. $(\mathrm{P}=0.05)$ & 17.94 & 11.58 & & \\
\hline
\end{tabular}

*-Mean of three replications, DAS- days after sowing,

Figures in parentheses are arc sine transformed values.

\section{Plate XV}

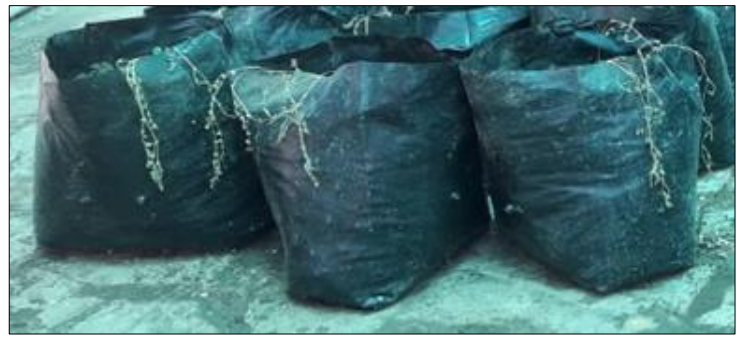

$35 \%$

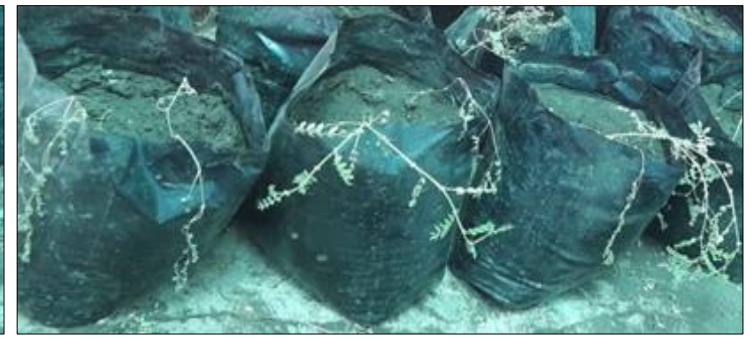

$40 \%$ 


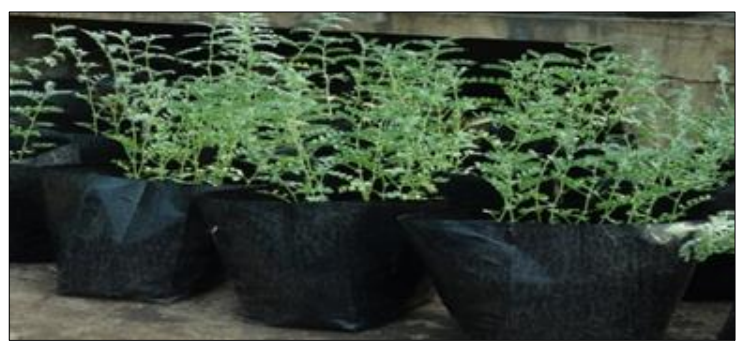

$55 \%$

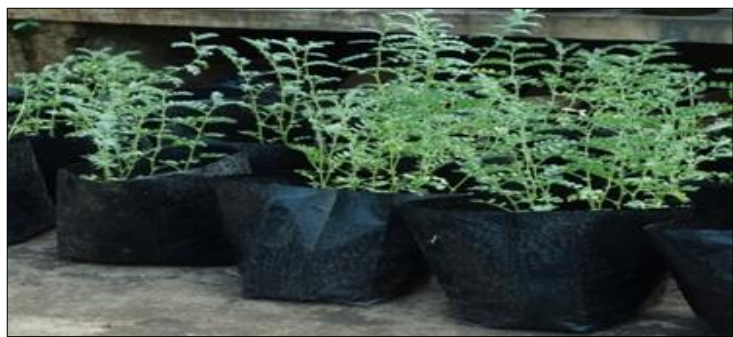

$\mathbf{7 5 \%}$

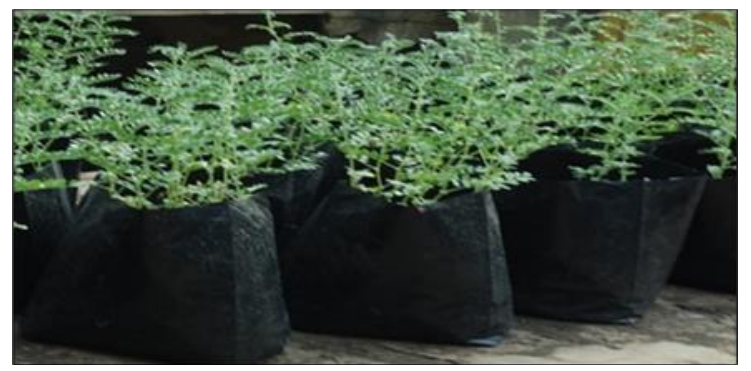

Effect of different soil moisture regimes on the incidence of Rhizoctonia bataticola



Fig 1: Effect of soil moisture regimes on the incidence of $R$. bataticola

Similar trend in respect of the dry root rot disease incidence was also observed at $30 \mathrm{DAS}$ and it was ranged from 16.67 to 100.00 per cent, as against none of the incidence at 100 per cent soil moisture. However, it was significantly highest at 35 and 40 per cent soil moisture (each $100.00 \%$ ), which may be due to water stress coupled with M.phaseolina/R.bataticola infection. These were followed by the soil moistures viz., 55 per cent $(96.67 \%)$. At soil moisture above 60 per cent, the disease incidence was found to be decreased drastically in the range of 86.67 to 13.33 per cent.

At 45 DAS, all the soil moisture levels tested exhibited similar trend of dry root rot disease incidence as that of observed at 15 and 30 DAS and it was ranged from 10.00 to 100.00 per cent, as against none of the incidence at 100 per cent soil moisture. However, the disease incidence at 35, 40,

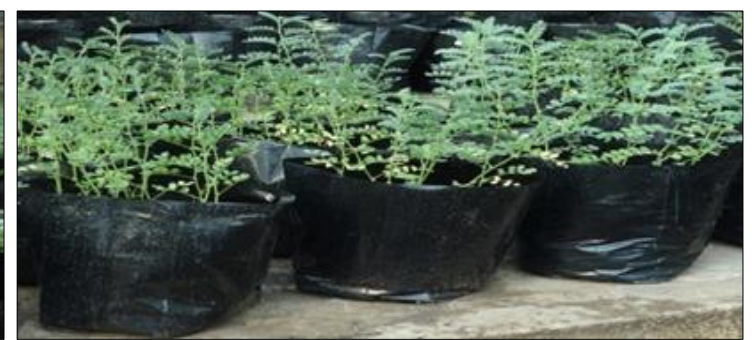

$60 \%$



$80 \%$

55 and 60 per cent soil moisture was significantly highest (each $100.00 \%$ ), which may be due to water stress coupled with R.bataticola /M.phaseolina infection. These were followed by the soil moisture viz., 75 per cent $(23.33 \%)$. At soil moisture of 80 per cent, the disease incidence was found minimum with 20.00 per cent.

The average disease incidence recorded at various soil moisture levels was ranged from 5.55 to 100.00 per cent, as against none of the incidence at 100 per cent soil moisture. However, average disease incidence at 35, and 40 per cent soil moisture was significantly highest (each $100.00 \%$ ), which may be due to water stress coupled with R.bataticola IM.phaseolina infection. These were followed by the soil moisture viz., 55 per cent $(80.00 \%)$. At soil moisture above 60 per cent, average disease incidence was found to be decreased drastically in the range of 74.45 to 13.33 per cent.

The environmental factors such as temperature and soil moisture plays major role in predisposing the chickpea crop to dry root rot disease incidence. Of these two major factors, water stress at the flowering stage of the crop seems to be most important predisposing factor for the initiation and development of dry root rot in chickpea and other crops like sorghum, sunflower, chickpea etc. Result obtained in the present studies also indicated that the average dry root rot disease incidence was also higher (range: 80.00 to 74.45 per cent) at the soil moisture level of 55 to 60 per cent.

Similar observations were recorded by Ratnoo et al., (1997) ${ }^{\text {[7] }}$ observed that disease development was low in flooded soil compared to drier soil (40 to $60 \%$ moisture). Sharma and Pande (2013) ${ }^{[9]}$ also observed difference in the dry root rot incidence with change in soil moisture content. The plants grown in control showed the physiological stress at $40 \%$ moisture as compared to $60 \%, 80 \%$ and $100 \%$. $40 \%$ soil moisture was insufficient for the normal growth of the plants. At $60 \%$ soil moisture, no physiological stress was found in control plants and dry root rot incidence was $100 \%$. Symptoms of dry root rot on aerial plant parts were found to be directly related with the disease severity on roots. Blackening of the roots initiated 5 days after maintaining the moisture stress at $40 \%$ and $60 \%$. Roots were apparently free from infection at $80 \%$ and $100 \%$. 


\section{Effect of soil types on the incidence of Rhizoctonia bataticola. (Pot culture)}

Results (Table 2, PLATE II \& Fig. 2) revealed that, the disease was significantly highest in sandy soil $(81.85 \%)$ followed by Sandy loam soil (71.85), Red soil (66.67) and Black soil (63.33). Comparatively minimum wilt incidence was observed in Clay soil (48.89\%).

Table 16: Effect of Different soil types on development of dry root rot incidence of chickpea

\begin{tabular}{|c|c|c|}
\hline Tr. No. & Treatments & PDI Mean \\
\hline T1 & Black Soil & $63.33(52.73)$ \\
\hline T2 & Red Soil & $66.67(54.73)$ \\
\hline T3 & Clay Soil & $48.89(44.36)$ \\
\hline T4 & Sandy Soil & $81.85(64.78)$ \\
\hline T5 & Sandy Loam Soil & $71.85(57.95)$ \\
\hline & SE $\pm(m)$ & 2.08 \\
\hline & CD at 5\% $(m)$ & 6.56 \\
\hline
\end{tabular}

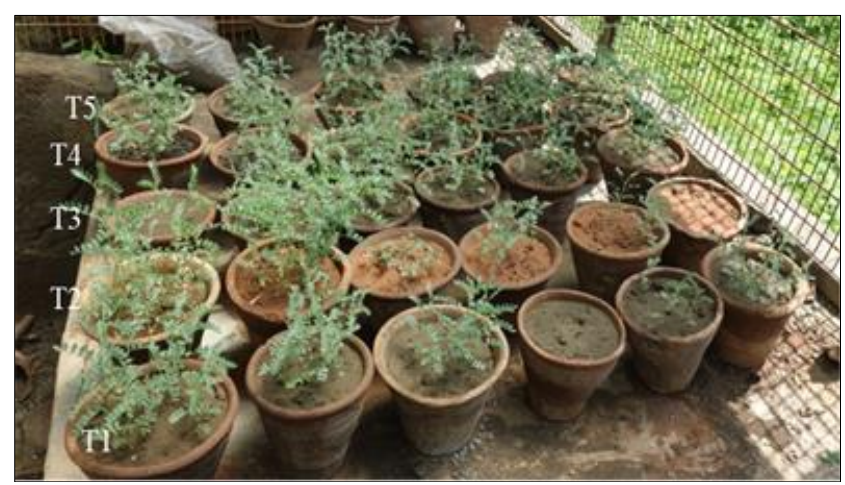

Plate II: Effect of Different soil types on development of dry root rot incidence of chickpea



Fig 2: Effect of Different soil types on development of dry root rot incidence of chickpea

Results of the present studies are in conformity with the earlier findings of workers Sagar and Sugha (1998) who reported highest pea wilt incidence in silty loam soil $(85.70 \%)$, sandy loam soil $(84.70 \%)$ and comparatively minimum wilt incidence in clay soil (78.50\%). Chandrasekaran and Shanmugam (1984) studied the effect of soil type on wilt incidence on chickpea root rot (Fusariumsolani) and reported highest disease incidence in sandy loam soil $(96.30 \%)$, followed by black soil $(53.80 \%)$ and red soil (35.00\%). Mallaiah and Krishna Rao (2016) reported that high incidence of dry root rot was in sandy loam $(11.1 \%)$ followed by sandy clay loam $(8.1 \%)$ and least in clay soils $(4.3 \%)$. While studying the effect of soil types on the incidence of chickpea dry root rot diseases, it was noticed that sandy soil showed highest dry root rot disease incidence than the other soil types. Maheswari \& Ramakrishnan (1999) [3] reported that the survival of sclerotia of $R$. bataticola in black soil was affected by high soil moisture (80\%), while the saprophytic activity of pathogen was maximum at low moisture levels (20, 30 and 40\%). The adverse effect of high soil moisture on survival of sclerotia of $R$. bataticola was also reported by Olaya and Abawi (1996) ${ }^{[4]}$ indicating that $R$. bataticola cannot survive for a longer period under anaerobic conditions.

\section{References}

1. Ghosh R, Sharma M, Telangre R, Pande S. Occurrence and Distribution of Chickpea Diseases in Central and Southern Parts of India. American J. of Pl. Sci. 2013; 4:940-944.

2. Hwang SF, Gossen BD, Chang KF, Turnbull GD, Howard RJ, Blade SF. Etiology, impact and control of rhizoctonia seedling blight and root rot of chickpea on the Canadian prairies. Canadian J. Plant Sci. 2003; 83:959-967.

3. Maheswari U, Ramkrishanan G. Factors influencing the competitive saprophytic ability of Macrophominaphaseolina in groundnut. Madras Agri. J. 1999; 86:552-553.

4. Olaya G, Abawi GS. Effect of water potential on mycelial growth and on production and germination of sclerotia of Macrophominaphaseolina. Plant Disease. 1996; 80(12):1347-1350.

5. Pande S, Desai S, Sharma M. Impact of climate change on rainfed crop diseases: Current status and future research needs. Lead papers presented in Nat. Symp. on Climate Change and Rainfed Agriculture, Hydrabad. 2010; 18-20:55-59.

6. Pande S, Sharma M, Nagavardhini A, Rameshwar T. High Throught Phenotyping of Chickpea Diseases: Stepwise identification of host plant resistance. Information Bulletin No.92 Patancheru 502 324, Andhra Pradesh, India: International Crops Research institute for the semi-Arid Tropics, 2012, 56.

7. Ratnoo RS, Jain KL, Bhatnagar MK. Variations in Macrophomina isolates of ash-grey stemblight of cowpea. J. Mycol. Pl. Pathol. 1997; 27:91-92.

8. Sharma M, Ghosh R, Pande S. Dry root rot Rhizoctonia bataticola (Toub.) Butler\}: an emerging disease of chickpea- where do we stand? Arch. Phytopath. Pl. Prot. 2015; 48(13-16):797-812.

9. Sharma M, Pande S. Unravelling effects of temperature and soil moisture stress response on development of dry root rot (Rhizoctonia bataticola (Taub.) Butler in chickpea. American J. of Pl. Sci. 2013; 4:584-589.

10. Sharma M, Mangala UN, Krishnamurthy M, Vadez V, Pande S. Drought and dry root of chickpea (Abstract). 5th International Food Legumes Research Conference (IFLRC V), 2010 \& 7th European Conference on Grain Legumes (AEP VII); 2010 April 26-30; Antlya: Akdeniz University \& Ministry of Agriculture and Rural Affairs under Auspices of International Steering Committee of IFLRC \& The European Association for Grain Legume Research (AEP), 2010.

11. Sunkaram A. Estimation soil moisture holding capacity. In: A Laboratory Manual for Agricultural Chemistry. Asia publishing Co., New Delhi, 1969, 332p. 